MT-DP - 2015/16

\title{
How does labour market structure affect the response of economies to shocks?
}

\author{
AURELIJUS DABUŠINSKAS - ISTVÁN KÓNYA
}

- STEPHEN MILLARD 


\title{
Discussion papers
}

MT-DP - 2015/16

Institute of Economics, Centre for Economic and Regional Studies, Hungarian Academy of Sciences

KTI/IE Discussion Papers are circulated to promote discussion and provoque comments. Any references to discussion papers should clearly state that the paper is preliminary. Materials published in this series may subject to further publication.

How does labour market structure affect the response of economies to shocks?

Authors:

\author{
Aurelijus Dabušinskas \\ Lietuvos Bankas \\ e-mail: ADabusinskas@lb.lt
}

István Kónya

senior research fellow

Institute of Economics - Centre for Economic and Regional Studies

Hungarian Academy of Sciences

and Central European University

e-mail: konya.istvan@krtk.mta.hu

\author{
Stephen Millard \\ senior economist \\ Bank of England \\ Durham University Business School \\ and Centre for Macroeconomics \\ e-mail: Stephen.millard@bankofengland.co.uk
}

April 2015

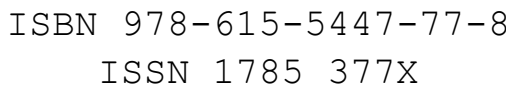




\title{
How does labour market structure affect the response of economies to shocks?
}

\author{
Aurelijus Dabušinskas - István Kónya - Stephen Millard
}

\begin{abstract}
The recent crisis in the Eurozone has led to much discussion about the structure of labour markets in different Eurozone economies. In particular, there has been much talk of the need for structural labour market reform in the Eurozone periphery. But, there are many aspects of labour market structure - eg, wage flexibility, flexibility in hiring and firing, benefits, etc and it is not clear a priori which aspects really matter. In this paper, we analyse how crosscountry differences in labour market characteristics - in particular, wage and employment rigidities - shape the response of different countries to a variety of macroeconomic shocks. To address this question, we use a calibrated small open economy model in which we set the parameters governing the structural characteristics of the labour market based on three European countries: Estonia, Finland and Spain. We found that, given our labour market calibrations, we would expect output and unemployment to be much more adversely affected by the shocks associated with the financial crisis in countries with high unemployment benefit replacement ratios and high job turnover rates.
\end{abstract}

Keywords: Labour market structure, Labour market flexibility

JEL classification: E24

\section{Acknowledgement}

The views expressed in this paper are those of the authors, and not necessarily those of the Bank of Latvia or the Bank of England.

The authors wish to thank participants in the Eurosystem's 'Wage Dynamics Network' for many helpful comments. Any errors and omissions remain the fault of the authors. 


\section{Miként befolyásolja a munkapiac felépítése a gazdaság alkalmazkodását exogén sokkokhoz?}

\section{Aurelijus Dabušinskas - Kónya István - Stephen Millard}

\section{Összefoglaló}

Az eurozóna közelmúltbeli válsága kapcsán jelentős hangsúlyt kaptak a tagországok különböző munkapiaci intézményei. Ezen belül is különösen fontos kérdés a munkapiac strukturális reformja az eurozóna perifériájának országaiban. A munkapiac felépítésének azonban számos jellemzője van - a bérek, illetve a felvételek és elbocsátások rugalmassága, a jóléti juttatások stb. - és előzetesen nem világos, hogy mely aspektusok a legfontosabbak. Ebben a tanulmányban azt vizsgáljuk, hogy a munkapiac felépítésének országok közötti eltérései - különösen a bérek és a foglalkoztatás merevségei - miként befolyásolják az országok különböző sokkokra történő alkalmazkodását. E kérdés megválaszolásához egy kalibrált, kis nyitott gazdaságos modellt használunk, amelyben a munkapiac intézményi felépítését vezérlő paramétereket három európai ország munkapiaca alapján állítjuk be: ezek Észtország, Finnország és Spanyolország. Fő eredményeink azt mutatják, hogy a pénzügyi válságot kísérő sokkok hatása a kibocsátásra és a foglalkoztatásra sokkal negatívabb azokban az országokban, ahol magas a munkanélküli juttatások bérekhez viszonyított aránya, illetve ahol nagyok a munkapiaci áramlások.

Tárgyszavak: munkapiaci intézmények, munkapiaci rugalmasság

JEL kód: E24 


\section{Contents}

$1 \quad$ Introduction and motivation $\quad 8$

2 The model $\quad 10$

$\begin{array}{llr}2.1 & \text { Households } & 10\end{array}$

2.2 Job flows $\quad 12$

2.3 The wholesale sector $\quad 13$

2.4 The retail sector $\quad 16$

$\begin{array}{lll}2.5 & \text { Equilibrium } & 17\end{array}$

$3 \quad$ Structural characteristics of our three economies $\quad 18$

$4 \quad$ Calibration $\quad 22$

$5 \quad$ How do our economies respond to shocks?

6 How does labour market structure affect the response of economies to shocks? 30

$7 \quad$ Conclusions $\quad 33$

$\begin{array}{ll}\text { References } & 24\end{array}$ 


\section{SUMMARY}

Since the financial crisis started in 2007, euro-area countries have experienced extremely divergent paths for economic growth, inflation and unemployment. Many economists have suggested that these divergent experiences can be put down to differences in the flexibility of the labour market in these different countries. In particular, it has often been argued that the financial crisis has brought to the forefront the need for labour market reforms in those countries that have performed badly. But, there are many aspects of labour market structure - eg, wage flexibility, flexibility in hiring and firing, benefits, etc - and it is not clear a priori which aspects really matter. In this paper, we analyse how cross-country differences in labour market characteristics - in particular, wage and employment rigidities - shape the response of different countries to a variety of macroeconomic shocks.

Much work has been done of late examining wage and employment dynamics in European countries. Some key findings of this research are that there is marked heterogeneity in labour market institutions across countries; that wages are reset less frequently than prices in a way that is both time-dependent and highly synchronised; that changes in base wages are linked to inflation but firms used other margins to adjust their wage bill; that real wages are marginally procyclical in most countries; that the wages of new hires tend to be linked to internal pay scales (ie, the wages of existing workers); that wages are downwardly rigid but whether this is real or nominal rigidity depends on the country; and that wages only partially feed through into inflation with the degree of passthrough depending on the degree of product market competition and the labour share. An important motivation for this paper was the need to assess the implications of these results for how different European economies might be expected to respond to macroeconomic shocks.

In our analysis, we are interested in answering the question of how might we expect nominal and real wage growth, employment and unemployment, output and inflation respond to financial intermediation, fiscal and external demand shocks in these different countries and how these responses are affected by differences in the countries' labour markets. In particular, would we expect real wages to be responding in a pro or countercyclical manner to the shocks and would we expect this to vary across different countries? To what degree might we expect the responses of wages and employment to vary across countries whose labour markets exhibit different degrees of wage and employment flexibility? To what extent do we expect changes in wages to feed through into relative prices and competitiveness? 
To answer these question, we use a calibrated macroeconomic model but adjust the parameters governing labour market structure in line with a number of Eurozone countries, where the chosen countries reflect labour markets that are more or less flexible in different dimensions. To be more precise we consider Estonia, Finland and Spain. We chose only Eurozone countries so as to avoid any issues around exchange rate movements and we chose these three particular countries because they reflect a variety of stages of economic development, a variety of unemployment rate responses to the financial crisis, and a variety of labour market features. The unemployment rate in Finland rose only a little in response to the crisis whereas the unemployment rate in Spain and Estonia rose markedly in response, since when the Spanish unemployment rate has stayed high while Estonia's has fallen back to its pre-crisis rate. The structural differences that we captured in our calibration included the job destruction and job finding rates and unemployment benefit replacement ratios. The relative rigidity of the Spanish labour market is reflected in its rather low job finding rate and high average unemployment rate whereas the Finnish and Estonian labour markets feature even higher job finding rates but have dramatically different income replacement ratios. Once we bring in our calibration of wage stickiness for existing and new employees, as well as wage indexation, categorising our labour markets as more or less flexible becomes more difficult. Nominal wages are fairly rigid in all our countries, with wages reset about once a year in all countries. Wage indexation is high in Finland and Spain but in terms of the extent to which (real) wages of newly hired employees are related to the wages of existing employees, and the bargaining power of workers more generally, Estonia emerges as more 'flexible' than the other countries.

We found that, given our labour market calibrations, we would expect output and unemployment to be much more adversely affected by the shocks associated with the financial crisis in Finland than in the other two countries. In terms of real wages, on the other hand, we would expect Spain and Estonia to be more adversely affected. These results are driven by the high unemployment benefit replacement ratio in Finland, the high job turnover in Finland and Estonia and the low worker bargaining power in Estonia.

Of course, in reality the Spanish economy was much more adversely affected by the financial crisis than the Finnish economy. Unemployment rose significantly in Estonia but quickly fell back again. This is likely to reflect the fact that the shocks affecting these economies were markedly different in this period, with the effect of the financial shock on Spanish risk premia - as picked up in the spread of Spanish bonds over German bunds being much larger than in the other countries, and necessitating a protracted period of fiscal consolidation that the model would pick up as a series of large negative government spending shocks. 


\section{INTRODUCTION AND MOTIVATION}

Since the financial crisis started in 2007, euro-area countries have experienced extremely divergent paths for economic growth, inflation and unemployment. Chart 1 illustrates this by plotting the unemployment rate in three different euro-area economies together with the unemployment rate for the Euro Area as a whole. Many economists have suggested that these divergent experiences can be put down to differences in the flexibility of the labour market in these different countries. In particular, it has often been argued that the financial crisis has brought to the forefront the need for labour market reforms in those countries that have performed badly. But, there are many aspects of labour market structure - eg, wage flexibility, flexibility in hiring and firing, benefits, etc - and it is not clear a priori which aspects really matter. In this paper, we analyse how cross-country differences in labour market characteristics - in particular, wage and employment rigidities - shape the response of different countries to a variety of macroeconomic shocks.

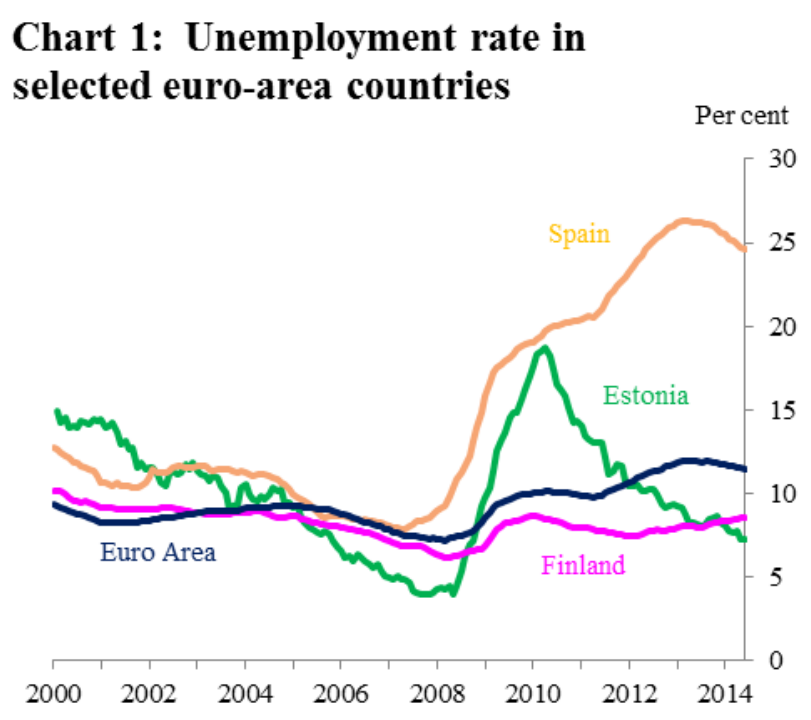

Much work has been done of late examining wage and employment dynamics in European countries. In particular, the Eurosystem's 'Wage Dynamics Network' (WDN) has carried out a survey of wage and price setting in 17 European countries, both inside and outside the Euro Area. ${ }^{1}$ Using data from this survey, Druant et al. (2010) examined the link between wage and price setting, Babecky et al. (2010) examined downward wage rigidity, Bertola et al. (2010) examined how wages and employment respond to shocks, and Galuscak et al. (2010) examined how the wages of newly-hired workers are determined. In addition, WDN researchers have sought to use recently available microeconomic data collected in

${ }^{1}$ See Druant et al. (2010) for a detailed description of the survey. 
different European countries to assess differences in labour markets across these countries. ${ }^{2}$ Some key findings of the WDN were that there is marked heterogeneity in labour market institutions across countries; that wages are reset less frequently than prices in a way that is both time-dependent and highly synchronised; that changes in base wages are linked to inflation but firms used other margins to adjust their wage bill; that real wages are marginally procyclical in most countries; that the wages of new hires tend to be linked to internal pay scales (ie, the wages of existing workers); that wages are downwardly rigid but whether this is real or nominal rigidity depends on the country; and that wages only partially feed through into inflation with the degree of passthrough depending on the degree of product market competition and the labour share. An important motivation for this paper was the need to assess the implications of these results for how different European economies might be expected to respond to macroeconomic shocks.

To answer this question, we use a calibrated macroeconomic model - that of Jakab and Konya (2009) - but adjust the parameters governing labour market structure in line with a number of Eurozone countries, where the chosen countries reflect labour markets that are more or less flexible in different dimensions. To be more precise we consider Estonia, Finland and Spain. We chose only Eurozone countries so as to avoid any issues around exchange rate movements and we chose these three particular countries because they reflect a variety of stages of economic development, a variety of unemployment rate responses to the financial crisis, and a variety of labour market features. In particular, as Chart 1 shows, the unemployment rate in Finland rose only a little in response to the crisis whereas the unemployment rate in Spain and Estonia rose markedly in response, since when the Spanish unemployment rate has stayed high while Estonia's has fallen back to its pre-crisis rate. In terms of structural features of the labour market, we can note that Spain's labour market is not particularly flexible whereas the labour markets of Estonia and Finland are fairly flexible. Spain and Finland both exhibit a large degree of downward real wage rigidity whereas wages in Estonia are flexible.

In our analysis, we are interested in answering the question of how might we expect nominal and real wage growth, employment and unemployment, output and inflation respond to financial intermediation, fiscal and external demand shocks in these different countries and how these responses are affected by differences in the countries' labour markets. In particular, would we expect real wages to be responding in a pro or countercyclical manner to the shocks and would we expect this to vary across different countries? To what degree might we expect the responses of wages and employment to vary

\footnotetext{
2 For example, du Caju et al. (2010a) examined differences in downward real and nominal wage rigidity across countries and du Caju et al. (2010b) examined inter-industry wage differentials in different EU countries.
} 
across countries whose labour markets exhibit different degrees of wage and employment flexibility? To what extent do we expect changes in wages to feed through into relative prices and competitiveness?

The structure of the paper is as follows. In the next section, we develop the model we are going to use to analyse the effects of these shocks before discussing the labour markets of the three countries we examine in Section 3. Section 4 discusses the calibration of the model, in particular, concentrating on the parameters governing the labour market in the different economies. Section 5 examines how we might expect the different economies to respond to financial, fiscal and foreign demand shocks. Section 6 illustrates how these responses depend on labour market structure and Section 7 concludes.

\section{THE MODEL}

In this section, we describe the open-economy model we are going to use. The model we use was developed in Jakab and Konya (2009). It is a small open economy model with search and matching in the labour market. Demand for the economy's exports will depend on their relative price and an exogenous foreign demand shock. Import prices are taken as given. Given that we are interested in Eurozone countries, we assume that import and export prices are denoted in the same currency and that interest rates are exogenous.

\subsection{HOUSEHOLDS}

The representative household maximizes their intertemporal utility by selecting streams of consumption, investment and domestic bond holdings. Consumption is subject to external habits, and investment is subject to adjustment costs. Household members are either employed or unemployed, but are able to fully insure each other against the random fluctuation of employment. This implies that the representative household member's utility function includes the average disutility of labour, $\chi$. We defer detailed discussion of the labour market to later.

The representative households' problem can be written as 


$$
\begin{aligned}
& \quad \max E_{0} \sum_{t=0}^{\infty} \beta^{t}\left[\frac{\left(c_{t}-h \bar{c}_{t-1}\right)^{1-\vartheta}}{1-\vartheta}-\chi n_{t}\right] \\
& \text { s.t. } c_{t}+i_{t}+\frac{a_{0}}{1+\varphi}\left(z_{t}^{1+\frac{1}{\varphi}}-1\right) K_{t-1}+\frac{b_{h, t}}{p_{t} e^{\varepsilon_{t}^{d}} R_{t}}+\tau=\frac{b_{h, t-1}}{p_{t}}+\left(1-u_{t}\right) w_{t}+u_{t} b_{u}+r_{t}^{k} z_{t} K_{t-1}+d_{t} \\
& K_{t}=(1-\delta) K_{t-1}+\left[1-\Phi\left(\frac{i_{t}}{i_{t-1}}\right)\right] i_{t},
\end{aligned}
$$

where $c_{t}$ is consumption, $\bar{c}_{t-1}$ is average consumption in the previous period, $n_{t}$ and $u_{t}$ are the employment and unemployment rates, respectively, $i_{t}$ is investment, $b_{h, t}$ is the level of risky nominal bonds held by the household, $R_{t}$ is the risk-free nominal interest rate, $p_{t}$ is the consumer price index, $\tau$ is a lump-sum tax that ensures that the government's budget is balanced in steady state with a zero net supply of bonds, $w_{t}$ is the real wage rate, $r_{t}^{k}$ is the (real) rental rate on capital, $K_{t-1}$ is the capital stock carried over from the previous period, $z_{t}$ represents the intensity with which the capital stock is used in period $t$, and $d_{t}$ is lump sum net income from other sources such as dividends and government transfers. We assume that the investment cost function is non-negative, and has the property that $\Phi(1)=\Phi^{\prime}(1)=0$ and we let $\Phi^{\prime \prime}(1)=\phi$.

We add a shock that drives a wedge between the central bank interest rate and the interest rate households face, as in Smets and Wouters (2007); that is, the gross return on risky bonds held by consumers will equal $e^{\varepsilon_{t}^{d}} R_{t}$. We think of this as capturing the shock to the ability of the financial system to intermediate between lenders and borrowers, resulting from the sub-prime crisis. Many recent models explicitly incorporate financial frictions into DSGE models, using mostly variants of the Bernanke et al. (1999) financial accelerator mechanism. 3 Since our purpose here is not to explain what caused the crisis, we treat the increase in financial frictions as exogenous. Also, since we estimate the interest rate wedge, our approach can be thought of as a reduced form for many different explanations of financial frictions. Our goal is simply to explore the consequences of an increase of the interest rate spread on the real economy, so we do not need to take a stand on the particular mechanism that caused the increase. For a similar approach looking at the US economy, see Hall (2009).

The first-order conditions for this problem (leaving aside labour supply for now) will be given by:

3 See, eg, Christiano et al. (2010) and Gertler and Karadi (2010). 


$$
\begin{aligned}
\left(c_{t}-h \bar{c}_{t-1}\right)^{-\vartheta}= & \lambda_{t} \\
\frac{\lambda_{t}}{P_{t}}= & \beta e^{\varepsilon_{t}^{d}} R_{t} E_{t} \frac{\lambda_{t+1}}{p_{t+1}} \\
1= & Q_{t}\left[1-\Phi\left(\frac{i_{t}}{i_{t-1}}\right)-\frac{i_{t}}{i_{t-1}} \Phi^{\prime}\left(\frac{i_{t}}{i_{t-1}}\right)\right] \\
& +\beta E_{t} \frac{\lambda_{t+1}}{\lambda_{t}} Q_{t+1}\left(\frac{i_{t+1}}{i_{t}}\right)^{2} \Phi^{\prime}\left(\frac{i_{t+1}}{i_{t}}\right) \\
Q_{t}= & \beta E_{t}\left[(1-\delta) Q_{t+1}+r_{t+1}^{k}\right] \frac{\lambda_{t+1}}{\lambda_{t}} \\
& \frac{a_{0}}{\varphi} z_{t}^{\frac{1}{\varphi}}=r_{t}^{k} \\
k_{t}= & (1-\delta) k_{t-1}+\left[1-\Phi\left(\frac{i_{t}}{i_{t-1}}\right)\right] i_{t} .
\end{aligned}
$$

The first equation defines the marginal utility of income, $\lambda_{t}$, the second equation is the household Euler equation, the third equation describes investment behaviour, the fourth equation is an arbitrage condition between investment into bonds and capital that defines the shadow value of capital, the fifth equation determines capital utilisation and the final equation defines the dynamic behaviour of capital.

\subsection{JOB FLOWS}

As is typical in the literature, we assume that new jobs are created when unemployed workers meet open job vacancies. The number of matches is described by a constant-returns-to-scale, Cobb-Douglas, matching function:

$$
m_{t}=\sigma_{m} v_{t}^{\sigma} u_{t}^{1-\sigma}
$$

where $m_{t}$ is the number of new matches, $v_{t}$ is the number of open vacancies, and $u_{t}$ is the number of unemployed. We follow the timing convention of Gertler et al. (2008) and assume that employment $n_{t}$ evolves according to the flow equation:

$$
n_{t}=(1-\rho) n_{t-1}+m_{t} \text {, }
$$

where $\rho$ is the exogenous separation rate and in which matches become productive immediately. 
We normalize the labor force to unity. Then unemployment will be given by

$$
u_{t}=1-n_{t-1}
$$

Thus workers who lose their jobs have to wait one period to be able to search for a new one, but those who enter the workforce can search immediately. Finally, we can define the job filling rate by $q_{t}=m_{t} / v_{t}$, the job finding rate by $s_{t}=m_{t} / u_{t}$ and labour market tightness by $\theta_{t}=v_{t} / u_{t}$

\subsection{THE WHOLESALE SECTOR}

Firms within the wholesale sector produce a homogenous product, using capital, imported intermediates and labour. Capital and imported intermediates are acquired at competitive factor markets at factor prices $r_{t}^{k}$ and $p_{t}^{m}$. The return on capital will be determined by market clearing in the domestic capital market whereas we assume that import prices are exogenous. The labour market, on the other hand, is subject to search-and-matching frictions. Each job is a firm-worker pair, subject to an exogenous job destruction probability $\rho$. The aggregate production function is given by the following Cobb-Douglas specification:

$$
Y_{t}=\left(z_{t} k_{t}\right)^{\alpha}\left(Y_{m, t}^{\alpha_{z}} N_{t}^{1-\alpha_{z}}\right)^{1-\alpha}
$$

where $Y_{t}$ is the amount of output produced, $k_{t}$ is the firm's demand for capital services (equal in equilibrium to the aggregate capital stock multiplied by its rate of utilisation), $Y_{m, t}$ is imported intermediates, $N_{t}$ is the number of workers employed, and as defined above, $z_{t}$ stands for capacity utilization. We assume that each firm employs one worker, so we can rewrite the production functions in a per-worker form as:

$$
y_{t}=\left(z_{t} k_{t}\right)^{\alpha} y_{m, t}^{\alpha_{z}(1-\alpha)}
$$

Given the Cobb-Douglas specification and the fact that the capital and import markets are competitive, demand for these inputs is given by the familiar conditions:

$$
\begin{aligned}
r_{t}^{k} z_{t} k_{t} & =\alpha p_{w, t} y_{t} \\
p_{m, t} y_{m, t} & =(1-\alpha) \alpha_{z} p_{w, t} y_{t} .
\end{aligned}
$$


This implies that the flow benefit of a job match for a firm is given by

$$
\xi_{t}=(1-\alpha)\left(1-\alpha_{z}\right) p_{w, t} y_{t}
$$

We base our description of the wage setting process on Bodart et al. (2006) and Konya and Krause (2008). In particular, we distinguish between the wage of new hires, and wages in existing jobs. Both wage-setting processes are described by a Calvo (1983) probability. In particular, wages in existing jobs are bargained with a probability $1-\gamma_{w}$; otherwise the wage is left at last period's value. For new hires, the wage is negotiated with probability $1-\vartheta_{w}$, otherwise it is indexed to last period's average wage $w_{t-1}$ (we discuss indexation below). We denote wages that are set optimally in period $t$ by $w_{t}^{*}$.

When a wage is not bargained over, it may still be adjusted to inflation. We allow for the following rule-of-thumb when wages are not bargained over: $w_{t}=\frac{w_{t-1}}{\pi_{t}^{\xi_{w}}}$, where $\pi_{t}=p_{t} / p_{t-1}$ is the inflation rate. Notice that since $w_{t}$ is the real wage, the specification nests full nominal $\left(\xi_{w}=0\right)$ and real wage rigidity $\left(\xi_{w}=1\right)$.

Let $V_{t}$ denote the value of a vacancy and let $J_{t}$ denote the value of a filled job.4 Since a vacancy is filled with probability $q_{t}$ and the wage bargain takes place with probability $\vartheta, V_{t}$ is given by

$$
V_{t}=-\frac{\kappa}{\lambda_{t}}+q_{t}\left[\vartheta_{w} J_{t}\left(w_{t-1}\right)+\left(1-\vartheta_{w}\right) J_{t}\left(w_{t}^{*}\right)\right]
$$

We assume the usual free-entry condition in the market for vacancies, which implies that the value of vacancies is identically zero, $V_{t} \equiv 0$.

Let $J_{t}\left(w_{t}^{*}\right)$ denote the value of a job that was renegotiated at $t$, and is given by:

$$
J_{t}\left(w_{t}^{*}\right)=\xi_{t}-w_{t}^{*}+\beta(1-\rho) E_{t} \frac{\lambda_{t+1}}{\lambda_{t}}\left[\gamma_{w} J_{t+1}\left(w_{t}^{*}\right)+\left(1-\gamma_{w}\right) J_{t+1}\left(w_{t+1}^{*}\right)\right]
$$

Unemployed workers receive an income $b_{u}$ while unemployed, and enjoy the monetized value of leisure $\chi / \lambda_{t}$. Thus, the value function for an unemployed worker, $U_{t}$, can be written as:

4 To save on notation, we will not explicitly indicate the indexation of past wages in the value functions. We make the indexation explicit whenever it is necessary in the formulas below. 


$$
U_{t}=b_{u}+\frac{\chi}{\lambda_{t}}+\beta E_{t} \frac{\lambda_{t+1}}{\lambda_{t}}\left\{s_{t}\left[\vartheta_{w} W_{t+1}\left(w_{t}\right)+\left(1-\vartheta_{w}\right) W_{t+1}\left(w_{t+1}^{*}\right)\right]+\left(1-s_{t}\right) U_{t+1}\right\}
$$

The value of a job when the wage is just negotiated is given by:

$$
W_{t}\left(w_{t}^{*}\right)=w_{t}^{*}+\beta E_{t} \frac{\lambda_{t+1}}{\lambda_{t}}\left\{(1-\rho)\left[\gamma_{w} W_{t+1}\left(w_{t}^{*}\right)+\left(1-\gamma_{w}\right) W_{t+1}\left(w_{t+1}^{*}\right)\right]+\rho U_{t+1}\right\}
$$

When wages are negotiated, we assume that they are set as a solution to the generalised Nash bargaining problem, as is standard in the literature.

Thus the wage $w_{t}^{*}$ solves:

$$
\max _{w_{t}^{*}}\left[W_{t}\left(w_{t}^{*}\right)-U_{t}\right]^{\eta} J_{t}\left(w_{t}^{*}\right)^{1-\eta}
$$

where the parameter $\eta$ measures the bargaining power of workers. The result of such a wage bargain is a wage that splits the combined surplus value of the job to the firm and worker between the firm and worker with the workers achieving a share of $\eta$ and the firms 1- $\eta$.

Using again equations (11), (12) and (13), we can rewrite the wage setting condition as follows:

$$
\begin{aligned}
w_{t}^{*}= & \eta\left(\xi_{t}+\frac{\beta \kappa}{\lambda_{t}} E_{t} \theta_{t+1}\right)+(1-\eta)\left(b_{u}+\frac{\chi}{\lambda_{t}}\right) \\
& +E_{t} \sum_{j=1}^{\infty} \frac{\lambda_{t+j}}{\lambda_{t}}\left[\beta \gamma_{w}(1-\rho)\right]^{j}\left[w_{t+1}^{*}-\frac{w_{t}^{*}}{\pi_{t+1} \xi_{w}}-\frac{s_{t+1} \vartheta_{w}}{(1-\rho) \gamma_{w}}\left(w_{t+1}^{*}-\frac{w_{t}}{\pi_{t+1} \xi_{w}}\right)\right]
\end{aligned}
$$

Thus the wage that is set at time $t$ is a combination of what it would be without any rigidity for existing jobs (the first two terms), and a term that captures the possibility that the newly set wage remains effective for some time period.

Recall that $w_{t}^{*}$ is the wage rate that is bargained at period $t$. The evolution of the average wage depends both on the newly set wage and on those wages that are not allowed to reset. Let $w_{t}$ denote the economy wide average wage, which evolves according to:

$$
w_{t}=\frac{m_{t}}{n_{t}}\left[\vartheta_{w} \frac{w_{t-1}}{\pi_{t}^{\xi_{w}}}+\left(1-\vartheta_{w}\right) w_{t}^{*}\right]+\frac{(1-\rho) n_{t-1}}{n_{t}}\left[\gamma_{w} \frac{w_{t-1}}{\pi_{t}^{\xi_{w}}}+\left(1-\gamma_{w}\right) w_{t}^{*}\right]
$$


Let us define the 'flexible wage' as:

$$
\omega_{t}=\eta\left(\xi_{t}+\frac{\beta \kappa}{\lambda_{t}} E_{t} \theta_{t+1}\right)+(1-\eta)\left(b_{u}+\frac{\chi}{\lambda_{t}}\right)
$$

which would be the wage under continuous Nash bargaining.

Log-linearising these equations, and noting that in the steady state $\bar{m}=\rho \bar{n}$, leads us to the following real wage Phillips curve:

$\hat{\pi}_{t}^{w}+\xi_{w} \hat{\pi}_{t}=\frac{\beta\left[(1-\rho) \gamma_{w}-\bar{s} \vartheta_{w}\right]}{\rho \vartheta_{w}+(1-\rho) \gamma_{w}}\left(E_{t} \hat{\pi}_{t+1}^{w}+\xi_{w} \hat{\pi}_{t+1}\right)+\frac{\left[1-\rho \vartheta_{w}-(1-\rho) \gamma_{w}\left[1-\beta \gamma_{w}(1-\rho)\right]\right.}{\rho \vartheta_{w}+(1-\rho) \gamma_{w}}\left(\hat{\omega}_{t}-\hat{w}_{t}\right)$

As the equation shows, wages are persistent, but real wage inflation is not. Wage persistence, intuitively, depends on three parameters: the exogenous Calvo (1983) probabilities $\gamma_{w}$ and $\vartheta_{w}$, and the job destruction rate $\rho$.

We can also derive the job creation condition:

$$
\begin{aligned}
\frac{\kappa}{\lambda_{t} q_{t}}= & \xi_{t}-w_{t}^{*}+\beta(1-\rho) E_{t} \frac{\kappa}{\lambda_{t} q_{t+1}}+\left[E_{t}\left(w_{t+1}^{*}-\frac{w_{t}^{*}}{\pi_{t+1}^{\xi_{w}}}\right)-\frac{\vartheta_{w}}{\gamma_{w}}\left(w_{t+1}^{*}-\frac{w_{t}}{\pi_{t+1}}\right)\right] \sum_{j=1}^{\infty} \frac{\lambda_{t+j}}{\lambda_{t}}\left[\beta \gamma_{w}(1-\rho)\right]^{j} \\
& +\vartheta_{w}\left(w_{t}^{*}-\frac{w_{t-1}}{\pi_{t}^{\xi_{w}}}\right) \sum_{j=0}^{\infty} \frac{\lambda_{t+j}}{\lambda_{t}}\left[\beta \gamma_{w}(1-\rho)\right]^{j}
\end{aligned}
$$

Notice that if there is no wage rigidity for new hires, ie, $\vartheta_{w}=0$, the job creation condition is identical to the one under continuous Nash bargaining. This is the point made by Pissarides (2009): for job creation and hence unemployment volatility, only the wages of new hires matter. With wage rigidity for new hires, however, job creation responds not only to next period's shocks, but also to the evolution of the average wage.

\subsection{THE RETAIL SECTOR}

The retail sector contains an infinite number of monopolistically competing firms, who buy the homogenous wholesale good and differentiate it. Consumers value the differentiated final goods according to the following CES utility function:

$$
y_{t}^{F}=\left[\int_{0}^{1} y_{t}^{F}(i)^{\frac{1}{1+\mu}} d i\right]^{1+\mu}
$$


where $y_{t}(i)$ is output of a typical variety in sector $i$, and $\mu$ is the desired mark-up. Demand for variety $i$ is then given by:

$$
y_{t}^{F}(i)=\left[\frac{P_{t}(i)}{P_{t}}\right]^{-(1+1 / \mu)} y_{t}^{F} .
$$

Price setting follows the basic New Keynesian model, based on Calvo (1983). In each period, a retail firm can reset its price optimally with probability $1-\gamma_{p}$. If it cannot reset its price optimally, it partially indexes its price to lagged inflation with the indexation parameter denoted by $\xi_{p}$. As is well known, these assumptions lead to the (log-linearized) New Keynesian Phillips curve:

$$
\hat{\pi}_{t}-\xi_{p} \hat{\pi}_{t-1}=\beta E_{t}\left(\hat{\pi}_{t+1}-\xi_{p} \hat{\pi}_{t}\right)+\frac{\left(1-\beta \gamma_{p}\right)\left(1-\gamma_{p}\right)}{\gamma_{p}} \hat{p}_{t}{ }^{w}
$$

where $\pi$ denotes inflation (and we have assumed zero inflation in steady state) and $p_{t}^{w}$ denotes the log deviation of real marginal cost (the wholesale price) from its steady state value, $1 /(1+\mu)$.

\subsection{EQUILIBRIUM}

Retail goods are sold domestically or exported. The wholesale sector is composed of $n_{t}$ firms producing $y_{t}$ units of the wholesale good each. Let $n_{d, t}$ denote the number of firms (and workers) who serve the domestic retail sector, then domestic final sales are given by $n_{d, t} y_{t}$. These are used for consumption, investment, and government consumption. The latter is assumed to be exogenous and unproductive, described by an autoregressive process. The domestic equilibrium condition is then given by:

$$
n_{d, t} y_{t}=c_{t}+i_{t}+g_{t}+\frac{a_{0}}{1+\varphi}\left(z_{t}^{1+\frac{1}{\varphi}}-1\right) K_{t-1}
$$

Government spending is financed by the lump-sum tax and by issuing bonds to households and foreigners: 


$$
p_{t} g_{t}=\tau+\frac{b_{h, t}}{e^{\varepsilon_{t}^{d}} R_{t}}-b_{h, t-1}+\frac{b_{f, t}}{e^{\varepsilon_{t}^{d}} R_{t}}-b_{f, t-1}-\chi_{b, f} b_{f, t}
$$

As discussed earlier, we assume that these government bonds are risky and denote shocks to the risk premium by $\varepsilon^{\mathrm{d}}$. Such shocks are a short-hand way of capturing the rise in spreads resulting from the financial crisis. And, as we said earlier, we assume that such bonds are in zero supply in steady state. In addition, we assume that the government has to pay an additional cost on the debt that is held by foreigners, $\chi_{b, f} b_{f, t}$. Given that we set $\tau$ so as to ensure the government's budget is balanced in steady state with a zero net supply of domestic bonds, this cost of holding foreign debt ensures that the model is stationary - with a steadystate net foreign asset position of zero - and also captures the fact that those countries which have issued too much debt to foreigners have had severe problems since the financial crisis started.

Monetary policy is assumed to be determined by the ECB and is exogenous to our three economies.

We posit an ad hoc export demand equation with export demand depending on the terms of trade and a foreign demand shock.

$$
\left(n_{t}-n_{d, t}\right) y_{t}=\left(\frac{p_{t}}{p_{m, t}}\right)^{-\theta_{x}} Y^{w} e^{\varepsilon_{t}^{x}}
$$

Finally, we can rewrite the household and government budget constraints to get the current account:

$$
\frac{b_{f, t}}{e^{z_{t}^{d}} R_{t}}-b_{f, t-1}=p_{m, t} n_{t} y_{m, t}-p_{t} n_{x, t} y_{t}+\chi_{b, f} b_{f, t}
$$

\section{STRUCTURAL CHARACTERISTICS OF OUR THREE ECONOMIES}

Before going on to discuss the data we use and the estimation itself, we first consider the structure and institutions characterising the labour markets of the three economies we consider. We do this because a key interest within this paper is how differences in labour market structure and institutions affect how these countries respond to macroeconomic shocks. Table A shows a set of structural indicators for the labour markets of our sample of 
countries. The table shows a number of labour market characteristics and reveals several important structural differences among the considered economies.

The top of the table shows three indicators that have direct counterparts among our model parameters: the net replacement rates (capturing the extent of unemployment benefits), and job finding and destruction rates. In terms of the generosity of unemployment benefits, our countries cover a range of cases, starting from the replacement rate of 52 percent in Estonia to 71 percent in Finland, whereas in terms of the intensity of labour flows, the countries broadly fall into two groups. The job finding and destruction rates are relatively high in Estonia and Finland but notably lower in Spain.

Our countries also differ with regard to unionisation and centralisation in wage bargaining. In Estonia union coverage is low (up to 35 percent), and wage bargaining is largely decentralised (takes place predominantly at the company level). In contrast, the coverage is high (above 80 percent), and wage bargaining is considerably more centralised in Finland and Spain, where it typically takes place at the national or regional and then sectoral level. (See Du Caju et al. (2008).) Interestingly, the average length of collective agreements also differs between the two groups: it is one year in Estonia but two and a half years in Finland and Spain. Of course, it is difficult to translate this evidence into what we might think of as 'bargaining power' in the model.

Comparable cross-country information on wage rigidity is scarce. The WDN survey evidence on wage setting at the firm level sheds light on the frequency of wage changes and indexation of wages to inflation but covers only two of our countries: Estonia and Spain. Concerning the frequency, the middle part of the table shows the percentage of firms that change wages more often than once a year and the share of those that do so yearly. This evidence suggests that for Estonia and Spain the model probability of no price change under Calvo's pricing should be about equal to 0.75. Note however that the implied average durations of wages computed by Druant et al. (2010) under the assumption that wage durations are distributed log-normally appear rather similar. 
Structural indicators

\begin{tabular}{|c|c|c|c|c|}
\hline & & Estonia & Finland & Spain \\
\hline \multirow{7}{*}{ 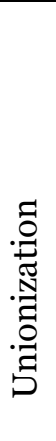 } & Net replacement rate $/ 1$ & 0.52 & 0.71 & 0.55 \\
\hline & Job finding rate $/ 2$ & 0.31 & 0.40 & 0.12 \\
\hline & Job destruction rate $/ 3$ & 0.033 & 0.037 & 0.015 \\
\hline & Union density /4 & Very low & Moderate & Very low \\
\hline & Union coverage, \% / 5 & 22 & 90 & \\
\hline & Principal bargaining level / 6 & Company & $\begin{array}{l}\text { National/ } \\
\text { sectoral }\end{array}$ & \\
\hline & $\begin{array}{l}\text { Average length of collective } \\
\text { bargaining agreements, years/7 }\end{array}$ & 1 & $2^{1 / 2}$ & $2^{1 / 2}$ \\
\hline \multirow{6}{*}{ 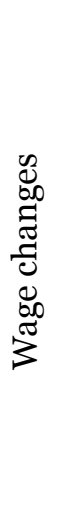 } & $\begin{array}{l}\text { Frequency of wage changes / } 8 \\
\text { - higher than yearly, \% of } \\
\text { firms }\end{array}$ & 19.9 & $\mathrm{Na}$ & 11.9 \\
\hline & - yearly, \% of firms & 64.4 & $\mathrm{Na}$ & 84.1 \\
\hline & $\begin{array}{l}\text { Implied duration of wages, } \\
\text { months } / 9\end{array}$ & 12.7 & $\mathrm{Na}$ & 11.9 \\
\hline & $\begin{array}{l}\text { Institutionalized wage } \\
\text { indexation } / 10\end{array}$ & None & High & High \\
\hline & $\begin{array}{l}\text { Automatic (rule-based) } \\
\text { indexation, \% of firms /11 }\end{array}$ & 4 & $\mathrm{Na}$ & 55 \\
\hline & $\begin{array}{l}\text { No rule, but inflation } \\
\text { considered, \% of firms / } 12\end{array}$ & 46 & $\mathrm{Na}$ & 16 \\
\hline \multirow{7}{*}{ 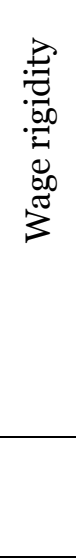 } & Downward wage rigidity / 13 & & & \\
\hline & - nominal & $\mathrm{Na}$ & 0.31 & 0.16 \\
\hline & Ieal & No & & 0.24 \\
\hline & $\begin{array}{l}\text { Importance of external labour } \\
\text { market conditions in hiring pay } \\
\text { determination, } \% \text { of firms / } 14\end{array}$ & 32.0 & $\mathrm{Na}$ & 4.4 \\
\hline & $\begin{array}{l}\text { Employment protection } \\
\text { legislation } / 15\end{array}$ & 2.39 & 2.29 & 3.11 \\
\hline & Monetary policy regime /16 & $\begin{array}{l}\text { Currency } \\
\text { board }\end{array}$ & Euro area & Euro area \\
\hline & Size, GDP, bill. euro (2007)/17 & 15.8 & 179.7 & 1053.5 \\
\hline
\end{tabular}

Notes:

(1) Estonia: net replacement rate, average over initial and long-term unemployment and two income levels (67 and 100 percent of average wage). Source: OECD, Benefits and wages: tax-benefit indicators (2007).

(2) Source: Hobijn and Sahin (2007) for Spain and Finland. The Estonian rate is calibrated on the basis of short-term (up to 3 months) and longer-term (more than 3 months) unemployment duration series over 2000Q-2009Q4, following Shimer (2005)

(3) Computed as steady state unemployment rate * job finding rate / (1- steady state unemployment rate). 
(4) Very low (0-25\%), low (26-50\%), moderate (51-75\%), high (76-100\%). Source:

Du Caju, et al. (2008).

(5) Source: Venn (2009).

(6) Source: Du Caju et al. (2008) ; see also Table 1 in Venn (2009).

(7) Source: Du Caju et al. (2008).

(8) Source: Druant et al. (2010).

(9) Estimated under the assumption that wage durations are distributed lognormally. Source: Druant et al. (2010).

(10) Percent of covered workers; very low (0-25\%), low (26-50\%), moderate (51$75 \%)$, high (76-100\%). In both Finland and Spain the high degree of indexation is implemented through collective agreements. Source: Du Caju et al. (2008).

(11) Source: Babecký et al. (2010).

(12) Source: Druant et al. (2010).

(13) The fraction of workers whose wages were not lowered in nominal (real) terms because of downward rigidity relative to the group of workers that might otherwise have experienced nominal (real) wage cuts. Source: Dickens et al. (2006) for Finland, Messina et al. (2010) for Spain.

(14) Employment-weighted average share of firms indicating that external market conditions (specifically, wages outside the firm and labour supply) are the most important factors determining the pay of newly hired employees. Source: Galuščak et al. (2010).

(15) OECD EPL index, ranging from o (weakest) to 6 (strictest) regulation. Source: Venn (2009).

(16) CB - currency board, with the euro as anchor currency; EA - euro area; IT inflation targeting.

(17) Source: Eurostat.

Both the WDN survey and institutional information can be also used to obtain insights on the extent and nature of wage indexation. There is no institutionalised wage indexation in Estonia, but Du Caju et al. (2008) suggest that the coverage of indexation implemented through collective agreements is high (exceeds 75 percent) in Finland and Spain. The WDN survey evidence on wage indexation at the firm level presented in Babecký et al. (2010) corroborates this: the share of firms practicing automatic (rule-based) wage indexation is found to be $4 \%$ in Estonia but $55 \%$ in Spain. The survey data also reveal that a relatively large proportion of firms in Estonia, 46\%, do not practice rule-based indexation but 'take inflation in account'. Hence, even though the incidence of explicit indexation in these countries is low, the overall degree of wage indexation may be higher because of less formal firm-level practices by which wages are adjusted to inflation. All in all, however, the evidence suggests that wage indexation - and by implication real wage rigidity - is more prevalent in Finland and Spain than in Estonia. The WDN survey findings about the main determinants of wages paid to newly hired employees provide indirect evidence on the relative flexibility of such wages across different countries. In this regard, Galuscak et al. (2010) consider the share of firms that indicated that external factors - wages outside the firm or availability of workers in the market - are more important in determining the wages of the newly hired than factors internal to the firm, such as collective agreements or the pay of incumbent workers. The corresponding figures for Estonia and Spain imply that external labour market conditions are the dominant factor for a substantially larger share of firms in Estonia (32\%) than Spain (4.4\%). In the context of our model, this would suggest that the Calvo parameter 
for newcomers' wages should be highest for Spain and lowest for Estonia. Similar empirical information is not available for Finland. Galuscak et al. (2010) show, however, that the importance of external factors in hiring pay determination is quite strongly negatively correlated with union density and coverage. This implies that the wages of new employees should be more sensitive to external factors in Estonia than Finland.

Since employment protection legislation (EPL) has implications for virtually all of the labour market characteristics considered above (worker flows, union bargaining power and wage rigidity, etc.), the table also reports the values of OECD EPL index for 2007.5 It follows that EPL is about equally strict in Estonia and Finland, but it is substantially more stringent in Spain.

To conclude, Table A suggests that, generally speaking, our countries represent two types of labour markets. The labour market of Estonia features relatively high employment flows, low union coverage and decentralised wage bargaining. In addition, Estonia has no institutionalised (or otherwise widespread) wage indexation. In contrast, the labour markets of Finland and Spain are characterised by high union coverage, centralised wage bargaining and relatively long collective contracts. Moreover, wage indexation, implemented through collective agreements, is pervasive in both countries, potentially resulting in higher real wage rigidity. ${ }^{6}$ But, we note that Spain differs from Finland in that it has two to three times lower labour turnover and considerably more stringent EPL.

\section{CAlibration}

We use a calibrated version of our model to examine how differences between the labour markets in our three countries affect their response to macroeconomic shocks. Most parameters are set identically for the three countries; these are shown in Table B. Parameters governing labour market structure, however, were set based on the results reported in Table A in the previous section; these parameter choices are shown in Table C.

We set $\beta=0.99$, which implies a real annual interest rate of $4 \%$ in steady state. Following Jakab and Konya (2009), we set the relative disutility of labour supply to 0.2. Following Millard (2011), we set the parameter governing the additional cost to the government of issuing debt to foreigners equal to 0.001. Following the estimation results of Smets and

\footnotetext{
5 Babecký et al. (2010) show that downward nominal wage rigidity increases with EPL.

${ }^{6} \mathrm{Du}$ Caju et al. (2008) discuss the results of cluster analysis conducted on the basis of wage bargaining characteristics in 23 European countries, the US and Japan. They consider three country groups and 2-4 finer sub-groups within them. They place both Finland and Spain in the second group (labour markets with regulated wage bargaining in which indexation and government intervention play an important role), whereas Estonia, Hungary and UK - in the third group (largely deregulated systems).
} 
Wouters (2003) we set the coefficient of relative risk aversion in the utility function to 1.6, the habit persistence in consumption parameter to 0.55 , the elasticity of capital adjustment costs to 6 , the elasticity of capital utilisation costs to 0.175 and the steady-state mark up to 1.5. We assume that prices are reset once a year on average (ie, se set the Calvo price-setting parameter to 0.75) and we follow the estimation results of Smets and Wouters in setting a degree of inflation indexation equal to 0.43. We also followed Smets and Wouters in setting $\delta=0.025$, which implies an annual depreciation rate of $10 \%$, and the cost share of capital to 0.3. We then set the import share of non-capital costs to 0.5 . We set the ratio of government spending to gross output to $15 \%$, a rough average of its value in the three economies. We assume an export demand elasticity of 0.5, in line with Burgess et al. (2012). These calibration choices are in Table B. Finally, in line with the general macro literature, we set the AR(1) parameters of all shocks except the mark-ups of domestic and export prices to o.9. The mark-up shocks are both assumed to be iid

Table B

\section{Standard parameters}

\begin{tabular}{c|l|c}
\hline Parameter & Description & Value \\
\hline$\beta$ & Discount factor & 0.99 \\
$\vartheta$ & Coefficient of risk aversion & 1.6 \\
$\chi$ & Relative disutility of labour supply & 0.2 \\
$\delta$ & Depreciation rate & 0.025 \\
$\alpha$ & Capital share of costs & 0.3 \\
$\alpha_{\mathrm{z}}$ & Import share of non-capital costs & 0.5 \\
$h$ & Degree of habit persistence & 0.55 \\
& consumption & \\
$\phi$ & Elasticity of capital adjustment costs & 6 \\
$\varphi$ & Elasticity of capital utilisation costs & 0.175 \\
$\gamma_{\mathrm{p}}$ & Calvo parameter for price-setting & 0.75 \\
$\xi_{\mathrm{p}}$ & Degree of inflation indexation & 0.43 \\
$\theta_{\mathrm{x}}$ & Elasticity of export demand & 0.5 \\
$\bar{\mu}$ & Steady-state mark-up - 1 & 0.5 \\
$\chi_{\mathrm{b}, \mathrm{f}}$ & Cost of issuing debt to foreigners & 0.001 \\
$\bar{g}$ & Share of government spending in gross & 0.15 \\
& output & \\
\hline \hline
\end{tabular}

Turning to the parameters governing the labour market shown in Table C, we first follow Petrongolo and Pissarides (2001) and set the matching elasticity to 0.5. For the job finding rate, job destruction rate and for the unemployment benefit replacement rate we used the results reported in Table A, above. The implied steady-state unemployment rates are $8.5 \%$ in 
Finland, 9.6\% in Estonia and $11.1 \%$ in Spain. The results of Table A suggest that, in all three countries, the wages of existing workers are reset once a year on average. In Spain, little regard is given to outside labour market conditions when setting the wage of new hires whereas in Estonia about a third of firms said they gave regard to external labour market conditions. So, we set the Calvo parameter for new hires to 0.75 (the same as existing employees) in Spain and Finland (which is as highly unionised as Spain) whereas we set it to 0.5 for Estonia. Based on Table A, we set the 'wage indexation' parameter to 0.5 in Estonia and 0.7 in Spain and Finland. Finally, in the absence of other information we set worker bargaining power to 0.5 in Spain and Finland, which have high union coverage as shown in Table A, and to 0.2 in Estonia, which has low union coverage.

Table C

\section{Labour market parameters}

\begin{tabular}{c|l|c|c|c}
\hline \multirow{2}{*}{ Parameter } & \multicolumn{1}{|c|}{ Description } & \multicolumn{3}{|c}{ Value } \\
\cline { 2 - 5 }$\gamma_{\mathrm{w}}$ & $\begin{array}{l}\text { Calvo parameter: wages of } \\
\text { existing employees }\end{array}$ & 0.75 & 0.75 & 0.75 \\
$\vartheta_{w}$ & $\begin{array}{l}\text { Calvo parameter: wages of new } \\
\text { employees }\end{array}$ & 0.5 & 0.75 & 0.75 \\
$\xi_{\mathrm{w}}$ & $\begin{array}{l}\text { Degree of wage indexation } \\
\sigma\end{array}$ & 0.5 & 0.7 & 0.7 \\
$b_{\mathrm{u}}$ & Matching elasticity & 0.5 & 0.5 & 0.5 \\
& Unemployment & & & \\
$\bar{s}$ & replacement ratio benefit & 0.52 & 0.71 & 0.55 \\
$\rho$ & Steady-state job finding rate & 0.31 & 0.40 & 0.12 \\
$\eta$ & Job destruction rate & 0.033 & 0.037 & 0.015 \\
\hline \hline
\end{tabular}

\section{HOW DO OUR ECONOMIES RESPOND TO SHOCKS?}

In this section, we consider the effects of standardised shocks on key variables in each of our economies. In the following section, we try and relate differences in these effects to differences in the various labour markets. We concentrate on the responses to shocks to domestic government spending, given the fiscal consolidation seen across the Euro Area, foreign demand and the domestic risk premium.

Starting with government spending shocks, Chart 2 shows that a $1 \%$ negative government spending shock has a similar - and relatively small - effect in each of our economies, where we have characterised them based on their labour market structure. That is, the lines are labelled 'Spain', 'Estonia' and 'Finland' not because we have a complete model of those economies but simply that the parameters of our model economies reflect the labour market features of each of them. Given the structural features of the different labour markets alone 
and holding everything else the same, we would expect the effect of this shock on Finnish output to be slightly larger than the effect on output in Spain and Estonia. The labour market responses are markedly different between the three countries as shown in Charts 3 and 4 . The government spending shock leads to a large fall in real wages and a small rise in unemployment in Spain and a much smaller fall in real wages and a much larger rise in unemployment in Finland. This is a surprising result given what happened in reality at that time, as shown in Chart 1: Finnish unemployment hardly rose at all whereas Spanish unemployment rose a great deal. What is perhaps surprising is that the model suggests that the structural features of the Estonian labour market lead to both small falls in real wages and small rises in unemployment in response to the shock. In Section 6, we investigate which particular features of the labour market lead to these seemingly inconsistent responses.
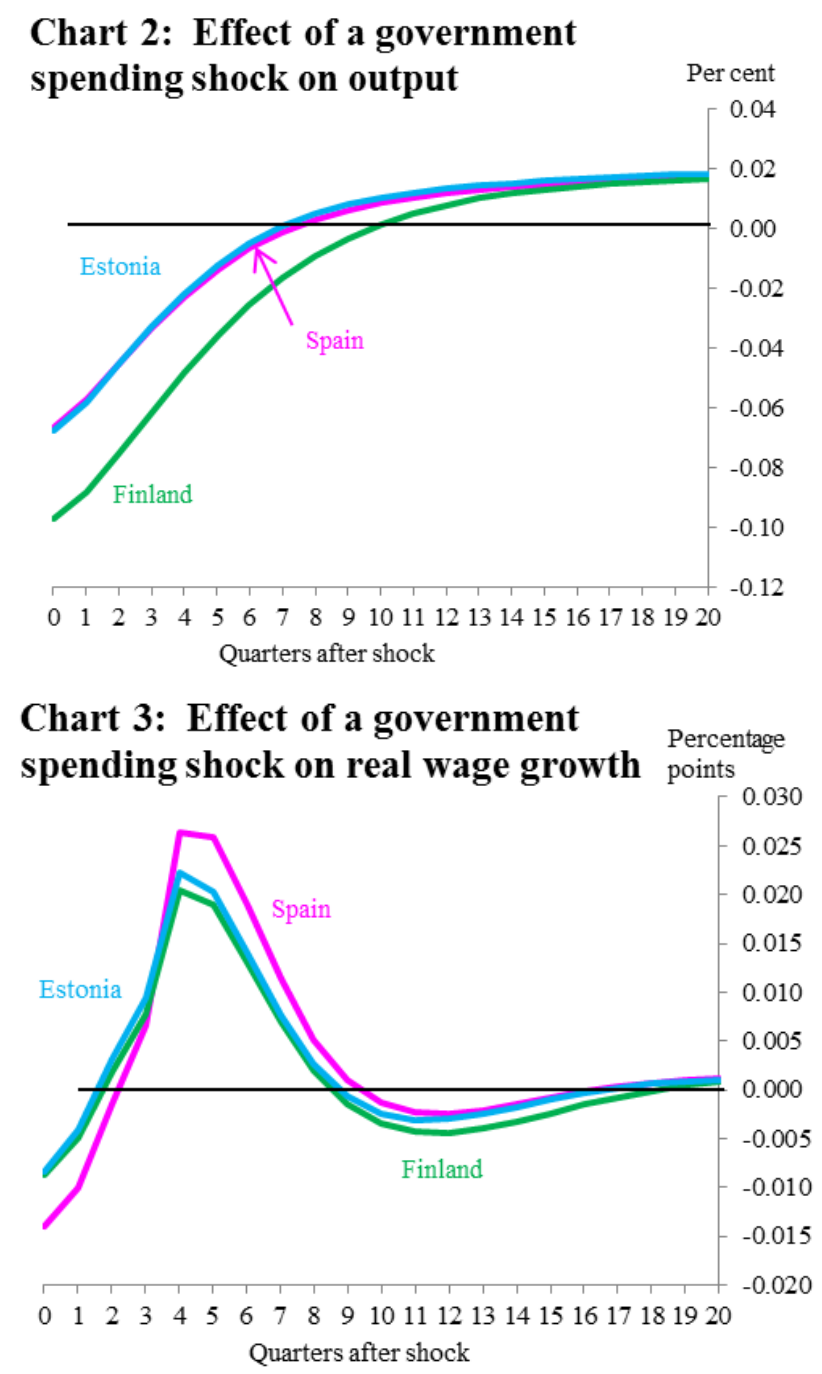

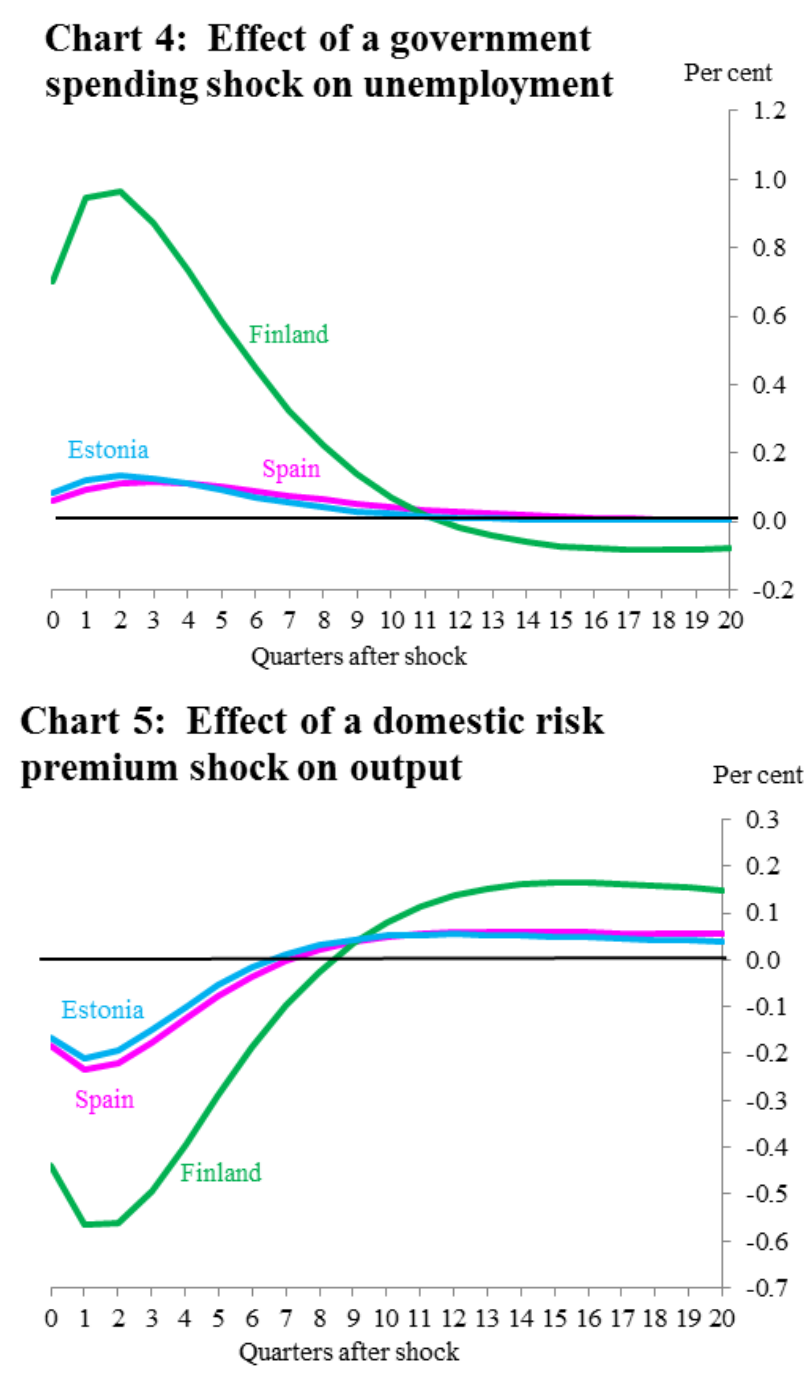

Chart 5 shows the response of output to a one percentage point rise in the domestic consumption risk premium, as a way of capturing the financial shock that affected the euroarea economies we consider. It shows that a given shock to the risk premium leads to a larger fall in output in an economy with the features of the Finnish labour market than in economies with the features of the Estonian and Spanish labour markets. The labour market responses are shown in Charts 6 and 7. The risk premium shock has a small impact on real wages and unemployment in the 'Spanish' and 'Estonian' labour markets but leads to a large rise in unemployment and a larger, though still small, fall in real wages in the 'Finnish' labour market. 

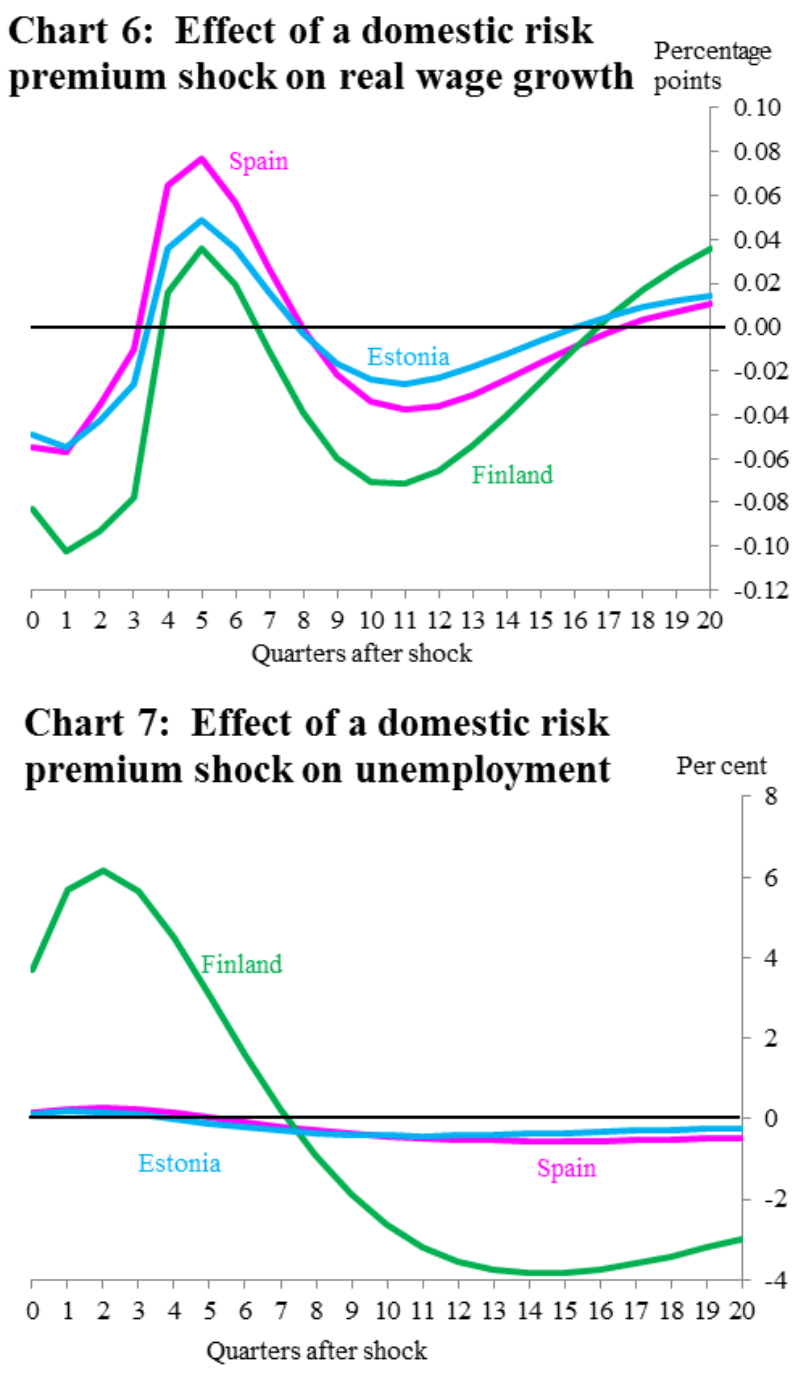

Chart 8 shows the response of output to a one percentage point fall in world demand. Again a given shock to world demand leads to a larger fall in output in an economy with the features of the Finnish labour market than in economies with the features of the Estonian and Spanish labour markets. The labour market responses are shown in Charts 9 and 10. Real wages fall by the most in an economy whose labour market displays 'Spanish' features and by the least in an economy displaying 'Finnish' features and unemployment rises by much more in a 'Finnish' labour market than in a 'Spanish' or 'Estonian' labour market. 
Chart 8: Effect of a world

demand shock on output

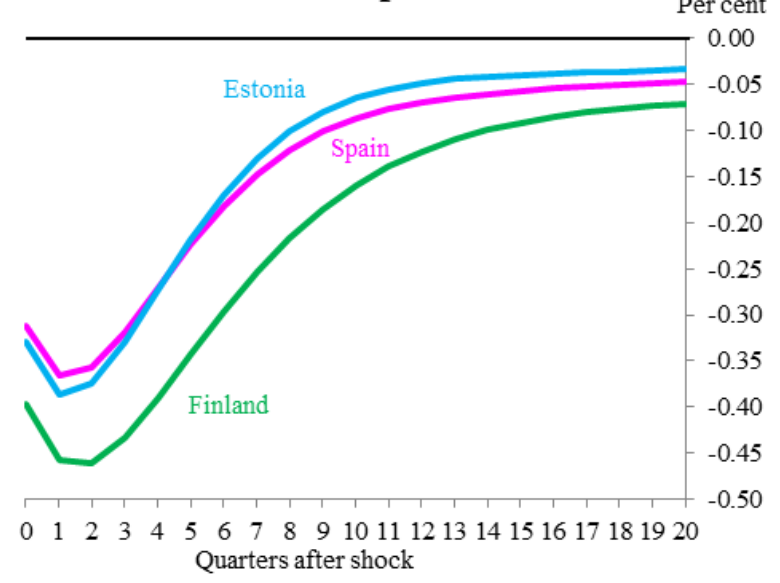

Chart 9: Effect of a world demand shock on real wage growth

Percentage

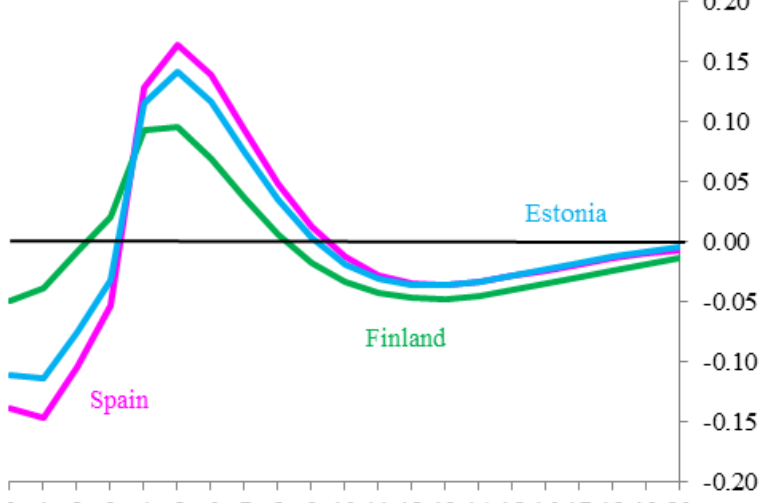

$\begin{array}{llllllllllll}0 & 1 & 2 & 3 & 4 & 5 & 6 & 7 & 8 & 9 & 1011 & 121314151617181920\end{array}$

Quarters after shock 

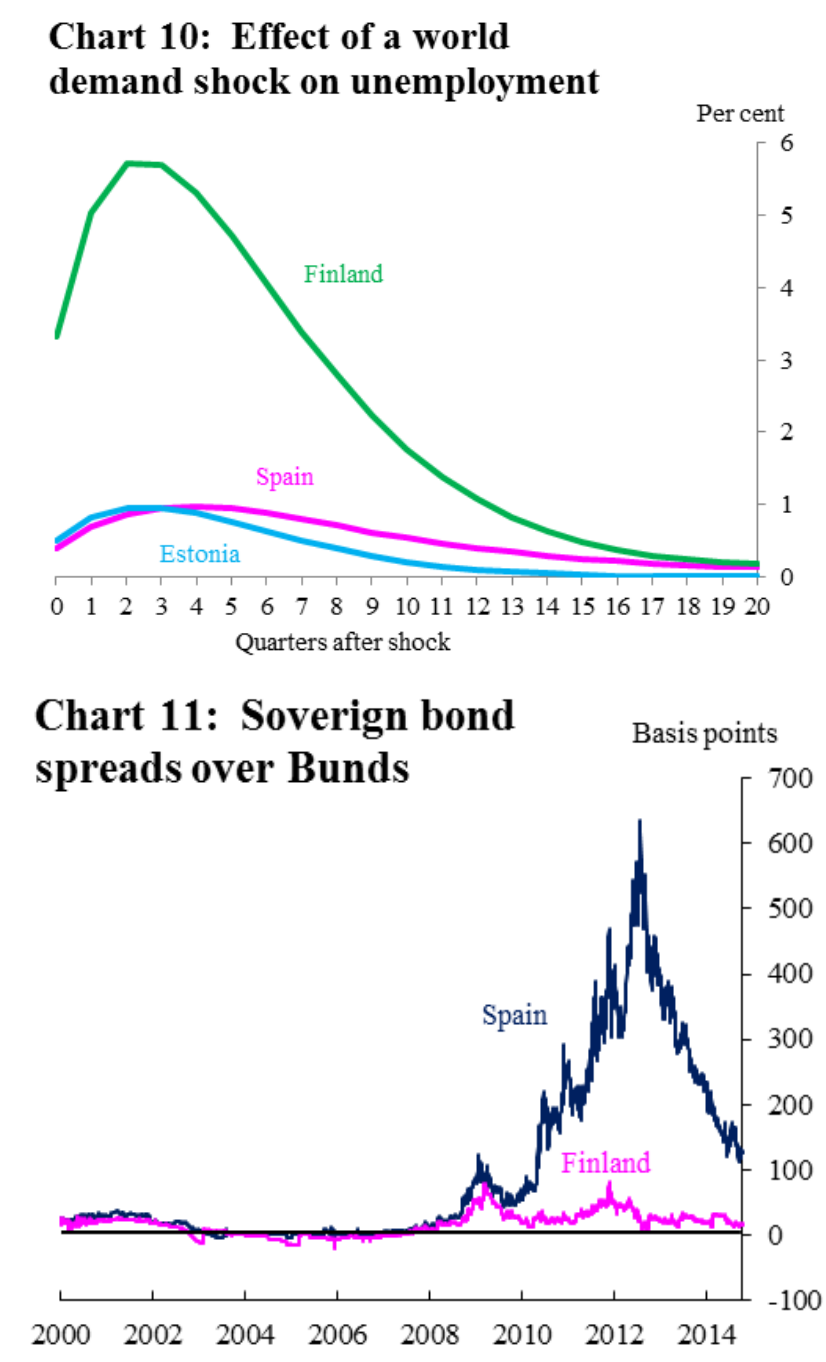

These results are surprising given that Chart 1 suggests that the rise in unemployment in the Finnish economy was the smallest of our three economies whereas the Spanish and Estonian unemployment rates rose by much more. The Estonian unemployment rate increased quite markedly and then fell back quickly, whereas the Spanish unemployment rate rose and then remained persistently high. Our model can explain the persistence but not the rise. One possible explanation is that Spain was affected by larger shocks than the other two economies. In terms of the financial shock, the behaviour of bond spreads shown in Chart 11 suggests that this was indeed the case. It is also the case that, if we assume the job destruction and job finding rates in Table $\mathrm{A}$ are indicative of the long-run values of these parameters, the steady-state rate of unemployment in Spain is about $21 / 2$ percentage points higher than that in Finland so we would expect to see higher unemployment in Spain than in Finland, and a given percentage increase in unemloyment in Spain will translate into a larger percentage point increase in the unemployment rate than in Finland. Finally, it is, of course, quite likely that other structural features of the three economies vary; such variations may explain some of the different responses though they remain outside the scope of this paper. 
All that said, it is instructive to examine exactly which labour market features matter for the responses of wages and unemployment to shocks. We consider this question in the next section.

\section{HOW DOES LABOUR MARKET STRUCTURE AFFECT THE RESPONSE OF ECONOMIES TO SHOCKS?}

In this section we attempt to analyse exactly which labour market features matter for the responses of real wages and unemployment to shocks. In order to conserve space, we concentrate on the financial shock; the effects of the other shocks are altered in similar ways. We use as our baseline the model as calibrated to the Spanish labour market since, in almost all regards, we can think of this as the least flexible labour market. We then change each parameter one at a time to its most flexible value and then examine the responses of real wages and unemployment to our financial shock in each case.

We start with the unemployment benefit replacement ratio, $b_{\mathrm{u}}$. Our baseline value calibrated to Spain - is 0.55. Chart 12 shows the response of unemployment to a financial shock in this case and in the case of $b_{u}=0.71$, the value of this parameter that we suggest fits the Finnish case. As can be seen, the unemployment response is much larger, both on the way up and on the way down. This goes some way to explaining the results of the previous section, which suggested that we might have expected a much larger response of unemployment in Finland to the financial shock than in Spain, conditional on the size of the shock. It is clear that further work is needed to investigate why the unemployment benefit system in Finland does not appear to have the same effect on unemployment dynamics in the data as it does in the model. 


\section{Chart 12: Effect of higher unemployment benefits on the unemployment response}

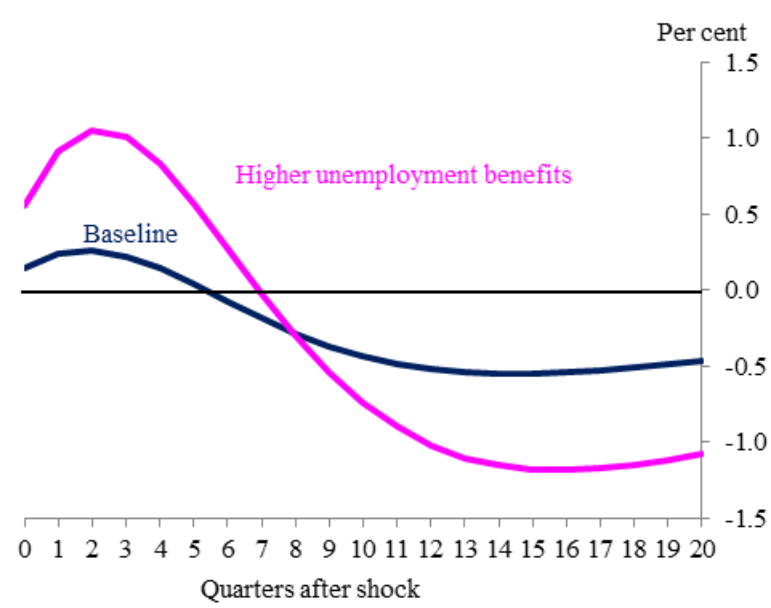

Chart 13: Effect of higher job finding rate on the unemployment response

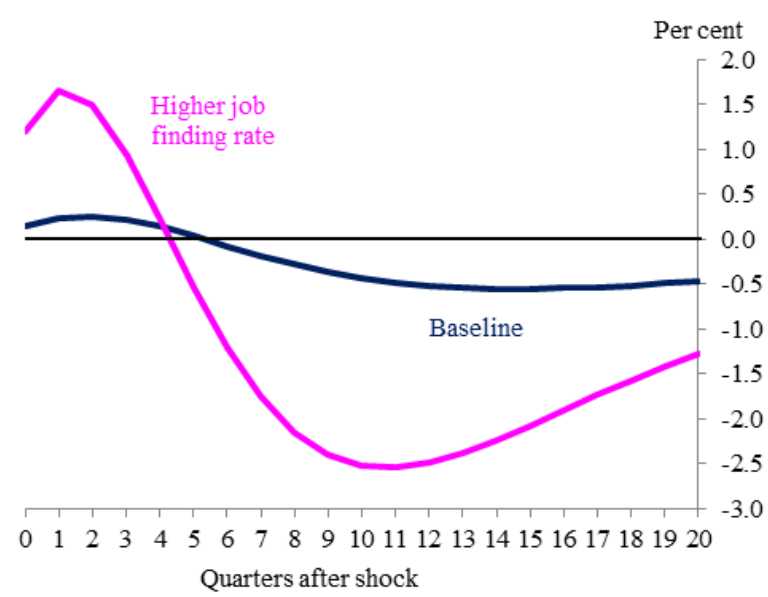

The other key difference between the Finnish labour market and the Spanish labour market is the high turnover seen in Finland relative to Spain.7 Chart 13 shows the response of unemployment to the financial shock in the baseline case where the job finding rate, $\bar{s}$, is set equal to 0.12 and in an alternative case in which we set it equal to the Finnish value of 0.4. As can be seen, the impact of the financial shock on unemployment is much larger in the high job-finding rate case than in the baseline case, but unemployment then falls quite markedly. This result explains the results shown in Charts 4 and 7 above, which show Finnish unemployment rising much more initially than Spanish or Estonian unemployment but then falling back quickly towards, and in fact undershooting, its lower steady-state level.

\footnotetext{
7 Recall this higher turnover is also associated with a lower steady-state rate of unemployment: $8.5 \%$
} in Finland vs. $11.1 \%$ in Spain. 

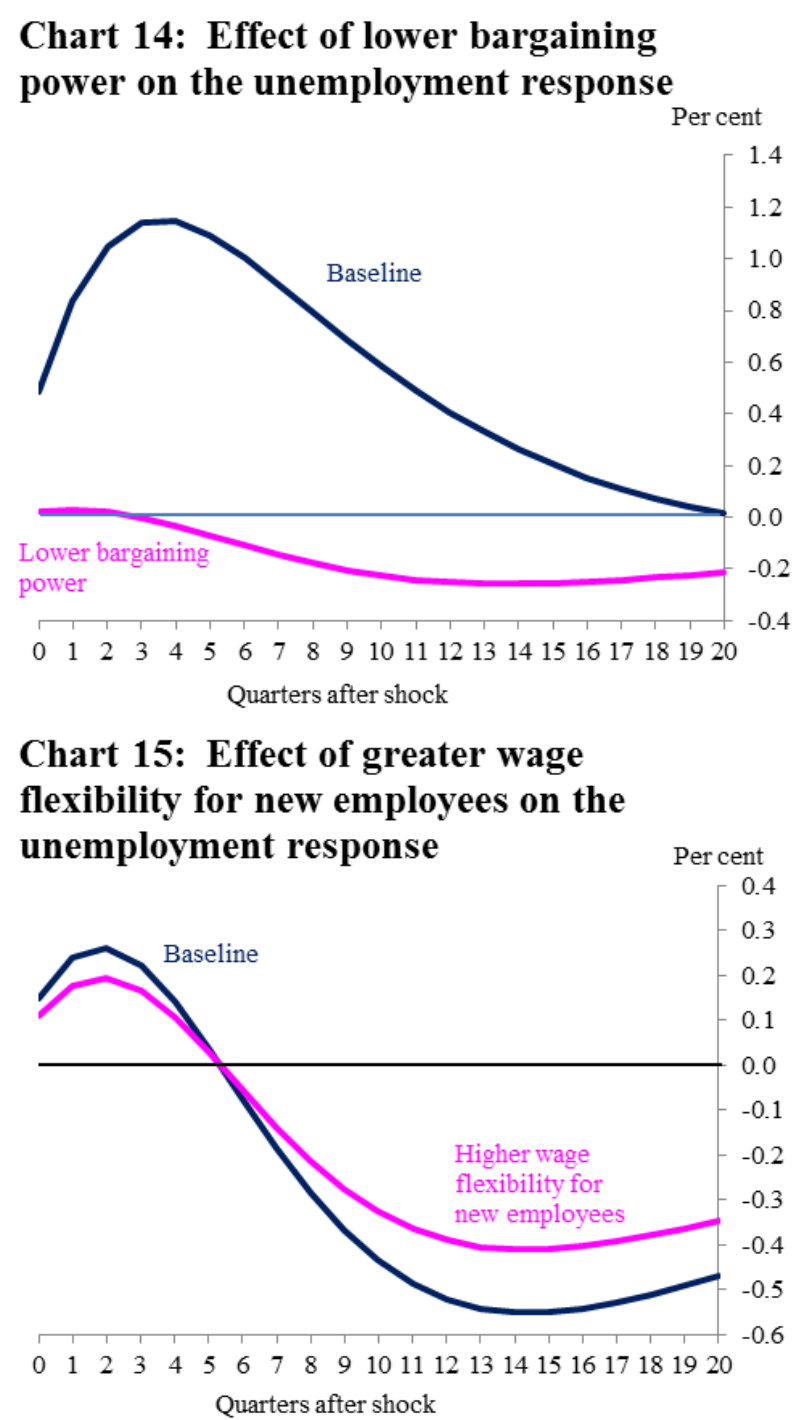

Now Estonia also has a much higher job finding rate than Spain. So why is the unemployment response in the Estonian parameterisation of the model similar to the response in the Spanish parameterisation? The answer can be seen from Charts 14 and 15 . Chart 14 shows the response of unemployment to a financial shock in the baseline case, where worker bargaining power, $\eta$, is set to 0.5 , and in an alternative case in which we set it equal to the Estonian value of 0.2. As can be seen, other things equal, lower bargaining power implies a much smaller response of unemployment to the shock, as firms push down on wages. Chart 15 examines the effect of wage flexibility among newly-employed workers. In the baseline case, the parameter is set to 0.75; in the increased flexibility case, it is set to the Estonian value of 0.5. Chart 15 suggests that this increased flexibility leads to a smaller unemployment response relative to the baseline case, as expected, but that the difference is much less marked than between the high and low bargaining power cases. Charts 13 through 15 suggest that different facets of the Estonian labour market relative to the Spanish labour market work in opposite directions in terms of the unemployment response to shocks. 


\section{CONCLUSIONS}

To address the question of how certain labour market features shape the ways in which different countries have adjusted to the recent financial and word trade shocks, we calibrated a small open economy model using labour market data on three European economies Finland, Spain, and Estonia - that differ in the extent of wage rigidity, labour turnover and other key labour market characteristics and examined how the responses of the model economy to standardised shocks depended on these labour market parameters. The structural differences that we captured in our calibration included the job destruction and job finding rates and unemployment benefit replacement ratios. The relative rigidity of the Spanish labour market is reflected in its rather low job finding rate and high average unemployment rate whereas the Finnish and Estonian labour markets feature much higher job finding rates but have dramatically different income replacement ratios. Once we bring in our calibration of wage stickiness, as captured by the Calvo parameters for the wages of existing and new employees, as well as wage indexation, categorising our labour markets as more or less flexible becomes more difficult. Nominal wages are fairly rigid in all our countries, with wages reset about once a year in all countries. Wage indexation is high in Finland and Spain but in terms of the extent to which (real) wages of newly hired employees are related to the wages of existing employees, and the bargaining power of workers more generally, Estonia emerges as more 'flexible' than the other countries.

We found that, given our labour market calibrations, we would expect output and unemployment to be much more adversely affected by the shocks associated with the financial crisis in Finland than in the other two countries. In terms of real wages, on the other hand, we would expect Spain and Estonia to be more adversely affected. These results are driven by the high unemployment benefit replacement ratio in Finland, the high job turnover in Finland and Estonia and the low worker bargaining power in Estonia.

Of course, in reality the Spanish economy was much more adversely affected by the financial crisis than the Finnish economy. Unemployment rose significantly in Estonia but quickly fell back again. This is likely to reflect the fact that the shocks affecting these economies were markedly different in this period, with the effect of the financial shock on Spanish risk premia - as picked up in the spread of Spanish bonds over German bunds being much larger than in the other countries, and necessitating a protracted period of fiscal consolidation that the model would pick up as a series of large negative government spending shocks. 


\section{REFERENCES}

Babecký, J, Du Caju, P, Kosma, T, Lawless, M, Messina J and Rõõm T (2010), Downward Nominal and Real Wage Rigidity: Survey Evidence from European Firms, Scandinavian Journal of Economics Vol. 112(4), pages 643-910.

Bernanke, B S, Gertler, $M$ and Gilchrist, $S$ (1999), 'The financial accelerator in a quantitative business cycle framework', in Taylor, $\mathrm{J}$ B and Woodford, M (eds.) Handbook of Macroeconomics, Elsevier: Amsterdam.

Bertola, G, Dabusinskas, A, Hoeberichts, M, Izquierdo, M, Kwapil, C, Montornès, $J$ and Radowski, $D$ (2010), 'Price, wage and employment response to shocks: Evidence from the WDN Survey', European Central Bank Working Paper No. 1,098. Bodart, V, de Walque, G, Pierrad, O, Sneesens, $H$ R and Wouters, $R$ (2006), 'Nominal wage rigidities in a New Keynesian model with frictional unemployment', National Bank of Belgium Research Paper No. 200610-9.

du Caju, P, Duarte, C F, Izquierdo, M, Messina, J and Hansen, N L (2o10a), 'The incidence of nominal and real wage rigidity: An individual-based sectoral approach', European Central Bank Working Paper No. 1,213. du Caju, P, Kátay, G, Lamo, A, Nicolitsas, D and Poelhekke, S (2010b), 'Interindustry wage differentials in EU countries: what do cross country time varying data add to the picture?', Journal of the European Economic Association, Vol. 8, pages 478-86.

Calvo, G A (1983), 'Staggered prices in a utility-maximising framework', Journal of Monetary Economics, Vol. 12, pages 383-98.

Christiano, C, Motto, $\mathbf{R}$ and Rostagno, $M$ (2010), 'Financial factors in economic fluctuations', European Central Bank Working Paper No. 1,192.

Dickens W T, Göte L, Groshen E L, Holden S, Messina J, Schweitzer, M E, Turunen, J and Ward $M$ E (2006), 'How wages change: Micro evidence from the International wage flexibility project', European Central Bank Working paper No. 697.

Druant, M, Fabiani, S, Kezdi, G, Lamo, A, Martins, F and Sabbatini, R (2o10), 'How are firms' wages and prices linked: Survey evidence in Europe', European Central Bank Working Paper No. 1,084.

Galuscak, K, Murphy, A, Nicolitsas, D, Smets, F, Strzelecki, P and Vodopivec, M (2010), 'The determination of wages of newly hired employees: Survey evidence on internal versus external factors', European Central Bank Working Paper No. 1,153.

Gertler, $M$ and Karadi, $\mathbf{P}$ (2010), 'A model of unconventional monetary policy', New York University mimeo.

Gertler, M, Sala, L and Trigari, A (2008), 'An estimated monetary DSGE model with unemployment and staggered nominal wage bargaining', Journal of Money, Credit and Banking, Vol. 40, pages 1,713-64.

Hall, R E (2009), 'The high sensitivity of economic activity to financial frictions', Stanford University mimeo.

Hobijn, B and Sahin, A (2007), 'Job-finding and separation rates in the OECD', Federal Reserve Bank of New York Staff Report No. 298.

Jakab, $Z$ and Konya, I (2009), 'An estimated open-economy DSGE model with searchand-matching frictions: The case of Hungary', Magyar Nemzeti Bank mimeo.

Konya, I and Krause, M (2008), 'Real wage dynamics in the Euro Area', Magyar Nemzeti Bank mimeo. 
Messina, J, Du Caju, P, Duarte, C F, Hansen, N L and Izquierdo M (2010), 'The incidence of nominal and real wage rigidity: An individual-based sectoral approach', European Central Bank Working Paper No. 1,213.

Millard, S P (2011), 'An estimated DSGE model of energy, costs and inflation in the United Kingdom', Bank of England Working Paper No. 432.

Petrongolo, B and Pissarides, $C A$ (2001), 'Looking into the black box: A survey of the matching function', Journal of Economic Literature, Vol. 39, pages 390-431.

Pissarides, C A (2009), 'The unemployment volatility puzzle: Is wage stickiness the answer?', Econometrica, Vol. 77, pages 1,339-69.

Shimer, R (2005), 'The cyclical behavior of equilibrium unemployment and vacancies', American Economic Review, Vol. 95, pages 25-49.

Smets, F, and Wouters, R (2007), 'Shocks and frictions in US business cycles: A Bayesian DSGE approach', American Economic Review, Vol. 97, pages 586-606.

Venn, G (2009), 'Legislation, collective bargaining and enforcement: Updating the OECD employment protection indicators', OECD Social, Employment and Migration Working paper No. 89. 